

\section{The Origins of Capitalism as a Social System}

Economists, historians and social scientists have offered a variety of conflicting answers to the issue of the beginnings of capitalism, and these deviating answers imply different conceptualizations of what capitalism actually is. This book provides a simultaneous inquiry into the origins of capitalism as well as provides a theoretical treatise on capitalism.

The Origins of Capitalism as a Social System explores the line between what is and is not capitalism, (re)producing a theory of capitalism as a system of class domination and exploitation. Part I focuses on the monetary theory of value and capital developed by Karl Marx, while at the same time critically reviews an array of economic and historical literature, both Marxist and non-Marxist. Following this, Part II expounds the first emergence of capitalism in Venice. It highlights the historical contingencies that made capitalism in the Venetian society possible, as well as the structural elements of the capitalist system and their interconnectedness. Finally, Part III discusses the capitalist character of the Venetian social formation from the end of the fourteenth century until the fall of the republic to Napoleon in 1797. As part of this, the author investigates the significance of forms of governmentality beyond national cohesion and territorialization.

Of great interest to economists, historians and both undergraduate and postgraduate students, this book gives special emphasis to a critical evaluation of the tensions and controversies among historians, economists and other social scientists with regard to the character and role that money and trade played in societies and economies.

John Milios is Professor of Political Economy and the History of Economic Thought at the National Technical University of Athens (NTUA), Greece. $\mathrm{He}$ is also Director of the quarterly journal of economic and political theory, Theseis (published since 1982 in Greek). 
In this grand style reconstruction of the genesis of capitalism, Milios brings together Marx, Braudel, Weber, Lenin, and his own analysis of 'moneybegetting' modes of production, under the aegis of the Althusserian 'aleatory encounter' of social forces. In a path-breaking concrete analysis, he invents the Venetian Paradigm of decalage between financialization and proletarianization. It is impressive, convincing, and surprisingly actual.

Etienne Balibar, co-author of Reading Capital

The publication of this book is a rather significant moment in the history of reflections on capitalism, and moreover a turning point in the history of the transformative present. Raising yet once again the question of what capitalism as a system actually is, John Milios reassembles his subject of study, traversing centuries and places in history so as to identify and discern heterogeneous practices being objectivised - or not - in the name of capitalism, ultimately establishing a genealogy of a 'capitalist state, beyond national territorialisation'. This book, or shall we dare say this 'machine-book', offers the bizarre completeness one might feel when reading an important book: full and empty at the same time.

Marios Emmanouilidis, Independent researcher

A fascinating book that provides us with an exciting new perspective on the origins of capitalism. John Milios asks more precisely than usual what distinguishes capitalism as a social system from precapitalist societies. Taking seriously that the origin of capitalism is a singular process, he avoids any deterministic approach to analyzing history. The - historically surprising ascent of Venice as a leading commercial and colonial power during the 13th and 14th centuries, with its rather special form of original accumulation towards the end of the 14th century, is demonstrated to be a capitalist social formation which practically introduced capitalism to Western Europe. This book really provides us with a fundamental and exciting new turn in the long-lasting discussion about the origins of capitalism.

Michael Heinrich, Author of An Introduction to the three Volumes of Karl Marx's Capital 


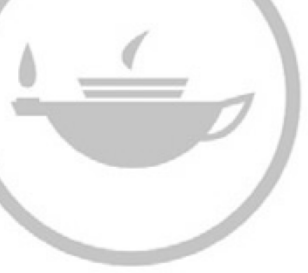

Taylor \& Francis Taylor \& Francis Group

http://taylorandfrancis.com 


\section{Routledge Frontiers of Political Economy}

232 Political Economy as Natural Theology

Smith, Malthus and Their Followers

Paul Oslington

233 Sharing Economies in Times of Crisis

Practices, Politics and Possibilities

Edited by Anthony Ince and Sarah Marie Hall

234 Philosophy in the Time of Economic Crisis

Pragmatism and Economy

Edited by Kenneth W. Stikkers and Krzysztof Piotr Skowron'ski

235 Public Policy and the Neo-Weberian State

Edited by Stanistaw Mazur and Piotr Kopycinski

236 The Economic Theory of Costs

Foundations and New Directions

Edited by Matthew McCaffrey

237 The Fascist Nature of Neoliberalism

Andrea Micocci and Flavia Di Mario

238 The Political Economy of Contemporary Spain

From Miracle to Mirage

Edited by Luis Buendía and Ricardo Molero-Simarro

239 The Origins of Capitalism as a Social System

The Prevalence of an Aleatory Encounter

John Milios

For a full list of titles in this series please visit www.routledge.com/books/ series/SE0345 


\title{
The Origins of Capitalism as a Social System
}

The Prevalence of an Aleatory Encounter

\author{
John Milios
}

\author{
Routledge \\ 而 Taylor \& Francis Group \\ LONDON AND NEW YORK
}


First published 2018

by Routledge

2 Park Square, Milton Park, Abingdon, Oxon OX14 4RN

and by Routledge

711 Third Avenue, New York, NY 10017

Routledge is an imprint of the Taylor \& Francis Group, an informa business

(C) 2018 John Milios

The right of John Milios to be identified as author of this work has been asserted by him in accordance with sections 77 and 78 of the Copyright, Designs and Patents Act 1988.

All rights reserved. No part of this book may be reprinted or reproduced or utilised in any form or by any electronic, mechanical, or other means, now known or hereafter invented, including photocopying and recording, or in any information storage or retrieval system, without permission in writing from the publishers.

Trademark notice: Product or corporate names may be trademarks or registered trademarks, and are used only for identification and explanation without intent to infringe.

British Library Cataloguing-in-Publication Data

A catalogue record for this book is available from the British Library

Library of Congress Cataloging-in-Publication Data

A catalog record has been requested for this book

ISBN: 978-1-138-03670-3 (hbk)

ISBN: 978-1-315-17839-4 (ebk)

Typeset in Bembo

by codeMantra 


\section{Contents}

Introduction

\section{PART I}

Capitalism and its origins: the theoretical context

2 Marx's two approaches to the genesis of capitalism: the 'productive forces - relations of production dialectic' vs. 'so-called original accumulation'

2.1 A note on the status of Marx's theoretical oeuvre 19

2.2 A 'philosophy of history' and a 'general law of human development'? 20

2.3 'So-called original accumulation' 24

3 Early forms of capitalism and wage labour: Lenin's polemic against the Narodniks

3.1 The historical context 31

3.2 Capitalism prevailed as pre-capitalist exploitation forms dissolved 34

3.3 Production for the buyer-up as a form of capitalist manufacture 36

3.4 Maintenance or dissolution of indirect forms of capitalist exploitation depending on class relation of forces 39

3.5 The theoretical importance of Lenin's intervention 42 
4 Capitalism and the agrarian sector: Karl Kautsky's theoretical intervention

5 Post-Second World War Marxist approaches to the 'transition to capitalism' question

5.1 The 'agrarian origin of capitalism' tradition 53

5.2 The 'State-Feudalism' tradition: revenge of the

Narodniks? 57

5.3 The persistent 'theory of Production Forces' tradition 62

5.4 The 'world-capitalism' tradition 64

5.5 The birth of capitalism as an aleatory encounter: from Balibar to Deleuze-Guattari and Althusser 67

5.6 The 'circulation question': Is merchant capital productive or not? 69

6 Non-Marxist approaches to the origins of capitalism

6.1 Introduction: the 'spirit of capitalism' and the riddle of monetary profit forms in pre-capitalist societies 78

6.2 Werner Sombart's Modern Capitalism and its critics (1902-1916) 79

6.3 Max Weber and the 'spirit of capitalism' controversy 85

6.4 'Ancient capitalism'? 88

6.5 Fernand Braudel: market economy vs. capitalism 91

7 Modes of production and the pre-capitalist money-owner

7.1 Modes of production and social classes: basic concepts and definitions 97

7.2 Dominant pre-capitalist modes of production: relations of use and possession in the hands of the labouring class 101

7.3 The money-begetting slave mode of production 103

7.4 A dominated non-capitalist mode of production persisting through time 106

7.5 The money-begetting slave mode of production and the capitalist mode of production 109

7.6 Economic partnerships as forms of pre-capitalist money-begetting activities 114

7.7 Concluding remarks 121 
PART II

Venice and the Mediterranean: a discourse on the birth of capitalism

8 From a Byzantine exarchate to a major colonial power in the Mediterranean: a historical sketch of the rise of Venice up to 1204

8.1 The emergence of the Italian maritime republics: an overview 131

8.2 Building a merchant tradition on salt, slaves and timber 133

8.3 Gaining power through alliance with Byzantium 136

8.4 The new geopolitical landscape after the First Crusade: phases of alliance and conflict up to the final clash of arms 139

9 The Venetian social formation until the end of the thirteenth century: an unconsummated process of original accumulation

9.1 The rule of a state-organized money-begetting oligarchy 148

9.2 The economic functions of the Venetian state 151

9.3 Complex forms of class exploitation and domination in a commercialized pre-capitalist society 154

9.4 Concluding remarks 160

10 War economics and the ascent of capitalism in the fourteenth century

10.1 The Venetian colonial system: countering tendencies of disintegration after the Fourth Crusade 164

10.2 Fighting for trade supremacy in the Mediterranean 166

10.3 State power and the consolidation of the relation of capital 170

\section{PART III}

After the encounter took hold: the reproduction of capitalism on an expanded scale

11 Venice alongside the new capitalist powers

11.1 Venice and capitalism in historiography and Marxist literature 187

11.2 Venice's supremacy in the fifteenth century 192 
x Contents

11.3 The Ottoman peril 193

11.4 The spread of capitalism in Europe and Venice's economic restructuring 194

11.5 Crises and recoveries 199

12 Political power and social cohesion

12.1 The Venetian state as a capitalist state 204

12.2 State apparatuses and forms of representation 206

12.3 The 'national question', Venice's state and its colonial territories 211

Bibliography

Index 


\section{Acknowledgements}

I would like to thank Paul Auerbach (Kingston University, London), Dimitri Dimoulis (Escola de direito de São Paulo da Fundação Getúlio Vargas, Brazil), Vassilis Droucopoulos (University of Athens), George Economakis (University of Patras), Marios Emmanouilidis (Independent Researcher, Thessaloniki), Dimitris Kyrtatas (University of Thessaly) and Dimitris P. Sotiropoulos (The Open University, UK) for having read drafts of the book and providing me with valuable observations that helped me to improve the quality of my work.

I am also indebted to several people at the international conference "150 Years Karl Marx's Capital: Reflections for the 21st Century" (Athens, 14-15 January 2017) who, during discussions of my theses on Marx's notion of 'original accumulation' and the pre-capitalist money-owner, raised questions that assisted in the development of my arguments while the book was still in the making.

A special mention is also owed to Barbara Santos for her valuable suggestions and for having improved the style of the manuscript. 


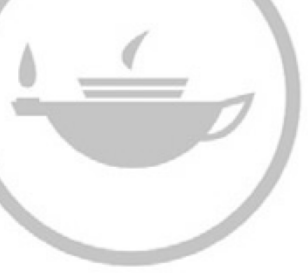

Taylor \& Francis Taylor \& Francis Group

http://taylorandfrancis.com 


\section{Introduction}

When did capitalism start? Economists, historians and social scientists have provided a wide variety of conflicting answers to this simple question. Let me mention only a few examples.

According to the leading twentieth-century economist John Maynard Keynes (1883-1946), capitalism was born in ancient Babylonia and thereafter was adopted by, or adapted to, ancient Greece and Rome, only to be later inherited by Western Europe (Keynes 2013). Prominent academic historians like Lujo Brentano (1844-1931), member of the so-called 'German Historical School', or Patricia Crone, of Princeton University (1945-2015), shared similar views (see Chapter 6).

According to Max Weber (1864-1920), who is often referred to as a 'founding father' of sociology and responsible for the Weberian theoretical tradition that followed, modern capitalism emerged from and was shaped in accordance with a spirit of abstinence introduced in Western societies by Calvinism, following the Reformation, which henceforth functioned as the 'spirit of capitalism' (Weber 2001; see also Chapter 6).

According to an enduring Marxist tradition, introduced shortly after the Second World War by the distinguished British economist Maurice Dobb (1900-1974) of Cambridge University, capitalism was first born in the agrarian sector of England in the late sixteenth and seventeenth centuries through the transformation of existing production assets from the feudal to the capitalist ownership form (see Chapter 5).

However, there have been totally divergent Marxist views as to whether agriculture was the focal point of capitalism's rise.

Karl Kautsky (1854-1938), probably the most influential Marxist at the turn of the nineteenth to the twentieth century, wrote in The Agrarian Question (first published in 1899), a book celebrated by V. I. Lenin as "the most important event in present-day economic literature since the third volume of Capital" (Lenin 1977, Vol. 4: 94), that capitalism, even if it succeeds in conquering the countryside (which was not the case in most capitalist countries), does so only after it has been established in the city: "capitalist agriculture only began to become significant once urban capital, and hence the credit system, had become well developed" (Kautsky 1988: 88; see also Chapter 4). 


\section{Introduction}

More recently, Oliver Cromwell Cox (1901-1974), a distinguished social scientist from Lincoln University of Missouri and inspired by Marxist theory, argued that it was not England, but "Venice, which nurtured the first capitalist society" (Cox 1964: xi) centuries before it conquered England. The eminent Marxist economist Ernest Mandel (1923-1995) also stressed the significance of "the accumulation of money capital by the Italian merchants who dominated European economic life from the eleventh to the fifteenth centuries" (Mandel 1968: 103) as a factor in the emergence of capitalism.

The famous French historian Fernand Braudel (1902-1985), a leading figure of the second generation of the 'Annales School', reached similar conclusions in regard to the origins of capitalism. He argued that capitalism first emerged as early as the thirteenth century, when "both Genoa and Venice" were "merchant and colonial powers (and the colonial tells us that they had already reached an advanced stage of capitalism)" (Braudel 1984: 118; see Chapter 11).

How can one explain such divergence of views as to when (and how) capitalism was born? How is it that theoreticians belonging to the same school of thought, as, for example, Marxism, reach totally conflicting conclusions?

This question, which has bothered me for quite some time as both a social scientist and a Marxist, seems easier to answer if one contemplates the issue of origins, or genesis, as follows: What was it that actually originated or was born? In other words, what is capitalism, whose genesis can be traced as a social process in history? Obviously, capitalism is a specific social structure, or equivalently, a social system, a historically unique configuration of social relations, which, according to the Marxist point of view, is built upon specific forms of class domination and exploitation.

At first glance, capitalism is a completely comprehensible term for Marxists (a system of exploitation of wage labour by capital), but to a great extent also for non-Marxists (the 'free market' economic system). However, what seems obvious at first glance is not at all obvious if one penetrates deeper into the constituent elements of the system under investigation and their forms of interconnectedness. Analyses on the 'beginning' or 'birth' of capitalism bring to the fore the divergent understandings of what features and social relations constitute the sine qua non of the capitalist system, with issues of money, trade and finance always dividing Marxist (and non-Marxist) social scientists, economists and historians.

It becomes clear that the differing approaches to the issue of the beginnings of capitalism denote, or rather imply, different conceptualizations of what capitalism actually is. This is because the theory of a system (or a structure) is the indispensable presupposition for one to comprehend when and how (i.e. through which processes) this system (or structure) was first formed - as a unique social system (structure) possessing specific differences from the systems that preceded or coexisted with it.

We may therefore conclude that (i) we need a theory of capitalism as a social system in order to be able to understand when and how capitalism emerged 
and that (ii) the broad divergence of opinions regarding the origins of capitalism reveals an equally broad divergence of opinions as to what capitalism as a system actually is.

Besides, what came to be was not destined to be. First, as Marcus Rediker of the University of Pittsburgh remarked nearly thirty years ago, "capitalism 'arrived in some parts of the production process much earlier than in others", (Rediker 1989: 341). In other words, the emergence of capitalism was initially a singular historical process that subsequently played a catalytic role in the spread of capitalist social relations in other territories. If one does not accept the singularity of the process of the genesis of capitalism, then it is assumed as if he/she accepts "that modes of production burst upon the historical scene Minerva-like, fully-formed" (Rediker op.cit.). Second, a singular process is always bound to a set of contingencies, i.e. it is by definition an aleatory process. According to Marxist theory, which provides the scientific investigation of social evolution, opposing trends and tendencies towards alternative paths of evolution can be traced to nearly all conjunctures of historic significance, reflecting in each and every case the dynamics of a particular balance of class forces. An assortment of eventualities of historical evolution is therefore repeatedly formed, and is not an 'iron necessity' of a predestined path of historical continuity or change. A scientific study of history refers precisely to the uncovering of these potentials and eventualities, and the understanding of the specific conditions that favoured the ultimate prevalence of a specific trend, which then materialized as a 'historical event'.

The two epistemological premises stated above imply that the study of the first traces of capitalism, or of its later dissemination in a social formation or territory, presupposes, on the one hand, a theory of capitalism as a system, and, on the other, a concrete analysis of the concrete situation under investigation; as György Lukács wrote, "the concrete analysis of the concrete situation [...] is the culmination of all genuine theory, its consummation" (Lukács 2009: 41-42).

The present book, being an inquiry into the origins of capitalism, is simultaneously a theoretical treatise on capitalism. The whole analysis has Karl Marx's theory as a point of departure, especially as developed in Capital and his other mature texts in the period between 1857 and 1881. As already stated, by endeavouring an investigation of the origins of capitalism, my analysis focuses on the demarcation line between what is and what is not capitalism, and in this sense presupposes, but also (re)produces, a theory of capitalism as a system of class domination and exploitation, and its structural characteristics.

The book contains three parts.

Part I focuses on the monetary theory of value and capital developed by Marx, at the same time critically reviewing an array of economic and historical literature, Marxist and non-Marxist. On this basis, it also illuminates historical forms of pre-capitalist money-begetting production and finance, which are often confused with capitalism. The book thus investigates the extent to which these money-begetting production forms facilitated the emergence of capitalism or coexisted with it. Part I comprises seven chapters. 
Chapter 1 highlights the fundamental characteristics that, in their interconnectedness, distinguish capitalism from all other social systems: (i) wage labour, (ii) monetization of the whole economy (money-begetting money), (iii) concentration of the means of production and dissociation of the capitalist from the labour process as such, (iv) free competition and the fusion of individual capitals into aggregate-social capital, (v) the financial mode of existence of capital and (vi) the formation of a specific juridical-politicalideological structure and a corresponding state form.

Chapter 2 deals with Marx's own contradictions in regard to the genesis of capitalism. Furthermore, the controversies and polemics among Marxists around the two, albeit contradictory, theoretical schemes that Marx himself formulated in his writings are discussed: on the one hand, the 'production forces - relations of production dialectic' and on the other, the 'so-called original accumulation' or the coming "face to face and into contact" (Marx 1887: 507) of the owners of money with the propertyless proletarians.

In Chapter 3, Lenin's contribution to Marxist theory concerning preindustrial capitalist economic forms is discussed. Lenin's analysis of the development of capitalism in Russia in the late nineteenth century is rendered useful in exploring arguments about the genesis of capitalism insofar as it sheds light on forms of the formal subordination of labour to (commercial) capital, and elucidates as capitalist, production processes that later Marxist theoreticians would consider to be feudal or 'pre-capitalist'.

In Chapter 4, Karl Kautsky's analysis on the 'agrarian question' is presented and critically assessed. According to Kautsky, capitalism first develops not in the countryside, but in the non-agrarian sectors of a country's economy, and especially in trade and finance. Following the dissolution of feudal social relations, the agricultural sector in a capitalist society is characterized by the tendency towards the creation and preservation of small- and medium-scale commercialized family farms. This form of simple commodity production complements industrial capitalism, as it itself is embedded in the overall process of capitalist reproduction: it provides agrarian commodities at relatively low prices, as these prices do not contain absolute rent and profit, and at best suffice for the subsistence of the farmer's family.

Chapter 5 critically presents (on the basis of theses and arguments developed in Chapters 1-4) post-Second World War debates among Marxist scholars on the 'transition from feudalism to capitalism': first, the debate initiated by Paul Sweezy's critique of Maurice Dobb's book Studies in the Development of Capitalism and the so-called 'Brenner debate'. Subsequently, it discusses alternative Marxist approaches on the rise of capitalism, such as the 'world capitalism' tradition and the 'aleatory encounter' between the money-owner and the proletarian approach, the latter initially introduced by Étienne Balibar in 1965, and later elaborated upon by Gilles Deleuze and Felix Guattari, and by Louis Althusser. The chapter culminates with an inquiry into an issue that constitutes one of the most disputed subjects in Marxist literature: the question of the productive or non-productive character of merchant capital, a subject about which Marx himself is sometimes ambiguous. 
In Chapter 6, I start by critically delineating the main arguments of the 'German Historical' debate on the origins of capitalism during the period 1902-1935, as it may serve to lay the groundwork for reflections on the monetary, 'entrepreneurial' and ideological-cultural origins of capitalism. The starting point of this debate was Werner Sombart's Modern Capitalism, a treatise first published in 1902, in which the notion of 'the spirit of capitalism' was coined as the indispensable pre-existing premise that made the emergence of capitalism possible. Soon after the publication of Sombart's book, the debate was fuelled, on the one hand, by its criticisms, and, on the other, by Max Weber's fully reshaping Sombart's concept, which was now comprehended in connection with the ideological climate allegedly brought to the fore by the Reformation. The chapter continues by commenting on more recent non-Marxist approaches to capitalism, which, like those of the 'German Historical' debate, substantially underestimate the structural role of wage labour in the formation of capitalism. Finally, Fernand Braudel's fruitful distinction between market economy and capitalism is discussed in connection with the lack of emphasis on class domination and exploitation, which characterizes the distinguished historian's oeuvre.

Concluding Part I, Chapter 7 utilizes the Marxist notion of the mode of production to exploit the critical conclusions of all previous chapters in an effort to provide the concept of the historical figure, which Marx describes as the pre-capitalist money-owner. In this context, two notions are introduced: (i) the money-begetting slave mode of production, existing since antiquity and clearly distinguishing itself from the classical (or "patriarchal", as Marx names it) slave mode of production and (ii) the contractual money-begetting mode of production that emerged in the Middle Ages in relation to financial schemes based on partnerships or associations. The 'contract' between the money-owner and the labourer, who in the latter case was free from all forms of personal servitude or bondage, entailed a complex form of exploitation. The labourer was in part a wage earner, but also had (limited) access to the ownership of the means of production (of 'capital') through both 'profit sharing' and the right to trade merchandise on voyages. In other words, he was not a proletarian, even if part of his income came from wage payment. The taskmaster of each of these two pre-capitalist modes of production is thus a pre-capitalist money-owner; his latter coming "face to face and into contact" with the labourer who has become a proletarian, that is, the emergence of capitalism, is discussed mainly in Part II.

Part II comprises three chapters and focuses on the emergence of capitalism in the city states on the Italian peninsula and more precisely in Venice, which until the end of the fifteenth century prevailed as a political, economic and colonial power in the broader Mediterranean area and beyond, and which also remained an independent state for more than eight centuries. My point of departure is not only existing historical research pointing to Venice's primacy as a money-begetting commercial and manufactural social formation, but also Marx's notion that "in Italy, where capitalistic production developed 


\section{Introduction}

earliest, $[\ldots]$ [the] free proletarian [...] found his master ready waiting for him in the towns" (Marx 1887: 508-509).

What differentiates my analysis from other approaches that stress the early development of capitalism in Venice and other city states on the Italian peninsula is my distinction between capitalist and non-capitalist forms of money-begetting 'entrepreneurial' activities. The most pronounced difference between capitalist and non-capitalist money-begetting activities is the 'taking hold' of the wage relationship as the main form of remuneration of labourers subjected to the rule of money-owners, or, in other words, the final incorporation of personal coercion into the economic relation as such.

In Chapter 8, I focus on the first phase of the history of Venice, up to 1204, outlining the main historical events that allowed her to be transformed from a former Byzantine province into an independent social formation, from an ally of the Byzantine Empire to the conqueror of Constantinople and from a provincial commercial town in the Adriatic into a major colonial power across the Mediterranean. Despite the fact that the whole process was linked to manifold historical contingencies - a concatenation of accidental circumstances and incidental causes - an explanation for this extraordinary ascent is equally sought in the social character, or the internal structure and cohesiveness, of Venetian society and the thereof derived strength of the Venetian state.

In Chapter 9, I analyze the historically unique class relations of power in the Venetian social formation, which functioned as pre-requisites to her success. The economic upswing of Venice never had as its 'prime mover' the 'private initiative' of certain ingenious merchants or any other 'self-made' and 'risk-taking' individuals. The 'instigator' of Venice's economic rise was the collectivity of a patrician class, having organized itself from the onset of the eleventh century as a militarized naval state that functioned as both coordinator and main undertaker of a multiplicity of money-begetting 'ventures': trade, piracy, plunder, slave trade, war, etc. Venice remained a pre-capitalist economy and society under the economic, political and social rule of a class of pre-capitalist merchants, ship-owners and directors of state-owned enterprises until the fourteenth century. The money-begetting activities of the Venetian ruling class constituted an unsettled process of original accumulation, in Marx's context of the term. One pole of the process, the Venetian money-owners and their state, had already attained the clearly defined characteristics of a spurious bourgeoisie. The other pole, however, the propertyless proletarian, had not yet emerged, and this is precisely why the bourgeoisie remained spurious. The wage-remunerated poor still participated in the ownership of the means of production through forms of 'association' mediated by the very fact of their being wage earners.

In Chapter 10, I investigate the historical contingencies chiefly related to economic antagonisms, the Venetian-Genoese wars beginning in the thirteenth century, the crises in the Venetian colonial system and the plague, all of which ultimately led to the prevalence of the capitalist mode of production 
in the second half of the fourteenth century in the Venetian social formation. These conditions led to the formation, in the late fourteenth century, of huge, state-owned manufactures organized on the basis of the capital - wage labour relation. It is clear that the encounter of the propertyless proletarian with the collective money-owner of the Venetian Commune clearly took hold in these manufactures. In parallel, all non-salaried sources of income of the majority of seamen were drastically restricted, creating a proletariat of wage-earning mariners. In this case as well, money-owners auctioning off state-owned fleets, and ship-owners commanding private ships became capitalists, as their coming "face to face and into contact" with the emerging proletariat took hold. In all instances where a lack of 'free labour' existed, forms of coerced labour, and above all the money-begetting slave mode of production, reappeared as a 'necessary' manifestation of 'entrepreneurship'. Finally, in order to support the wars, a huge internal public debt was created, which nurtured both advanced budgetary management and fiscal policies, and greatly expanded capitalist finance. By the end of the fourteenth century, Venice emerged as a capitalist social formation, practically introducing capitalism in Europe.

Part III expounds the capitalist character of the Venetian social formation from the end of the fourteenth century until the final subjugation of the republic to Napoleon in 1797. It comprises two chapters.

Chapter 11 mainly focuses on the economic restructuring and changing geopolitical role of Venice after the spread of capitalism in Western Europe, the expansion of the Ottoman Empire and the consolidation of large European territorial states. It also reviews various historiographical treatises and Marxist perspectives on the character of Venetian society. Venice remained a capitalist social formation until the last days of her existence, despite the fact that her prominence in European economy and politics had been receding since the sixteenth century, as capitalist social relations spread throughout Western Europe and new economic and military powers emerged. From the late sixteenth century, as Venetian commercial supremacy was challenged by new competitors, a restructuring of the Venetian economy took place based on the rapid growth of the manufacturing and financial spheres. Furthermore, Venice succeeded in becoming a significant colonial power in the Mediterranean with its colonial territory extending out into the eastern Mediterranean and Aegean Seas, in Dalmatia and Istria (the Stato da Màr), and on the Italian mainland (the Domini di Terraferma). Despite Ottoman expansion, which had been gradually chipping away at Venice's eastern colonies since the sixteenth century, both colonial dominions were sustained until the republic's demise, being shaped as hybrid sovereignties, somewhere between a colonial realm and a confederation of dominions.

Finally, Chapter 12 focuses on the Venetian state, highlighting its capitalist features. At the same time, it criticizes certain views claiming that Venice (and other city states on the Italian peninsula) 'failed' to become actual capitalist social formations because they could not develop a 'national political entity'. 
The capitalist state 'condenses' the overall rule of capital in a social formation, at the same time presenting it as being in the 'common interest' of society. In other words, the capitalist state must always homogenize every community within its political territory into an indigenous population supposedly possessing common interests and distinguish it from the 'other' (the populations of other states or territories). This means that the strategic interests of the capitalist class that are being 'condensed' by the state always entail a compromise with the subaltern classes. Modern nation-building and nationalism have played an important role in the homogenization of a capitalist state's indigenous populations: the nation constitutes the historically shaped and specifically capitalist unity (cohesion) of the antagonistic classes of a social formation, tending to unify the 'internal' and demarcate and distinguish it from the 'external', i.e. the 'non-national'. The process of nation-building, however, was initiated in Europe centuries after capitalism had established its rule in many social formations and parts of the continent. Nationalism and national identity emerged in the late eighteenth and nineteenth centuries, roughly in the wake of the French Revolution.

The Venetian state had acquired two basic characteristics of a capitalist type of state as early as the fourteenth century: the impersonal functioning of state apparatuses based on the 'rule of law' and 'equal justice' for all inhabitants of Venetian territory, regardless of their special status (patricians, citizens by birth, 'popolari', immigrants, servants or slaves) and the 'relative autonomy' of the state and its political and economic functions or interventions from all fractions of the ruling class, so as to establish the strategic interests of the Venetian bourgeoisie as being 'common interests' of the republic. Both elements played a decisive role in creating consensus for political power by the subaltern classes, and also by colonial populations and immigrants settling in Venice from other parts of the Mediterranean and the Italian peninsula.

Being not just a city state but a colonial empire, Venice developed institutions and techniques through which heterogeneous populations were dealt with on collective and statistical - on impersonal - terms. The Venetian capitalist state, without being a national state, successfully created forms of economic and social interaction, coercion, republican representation and loyalty to authorities, which facilitated the expanded reproduction of capitalist relations of exploitation and domination, while simultaneously preserving a multicultural society.

From this point of view, the lack of a national - Italian - identity (the disastrous Venetian-Genoese wars never contained an element of civil war) seems to me to be less an element of archaism and more a return to the future. 


\section{References}

Abulafia, David (1977) The Two Italies: Economic Relations between the Norman Kingdom of Sicily and the Northern Communes, Cambridge: Cambridge University Press.

Abulafia, David (2012) The Great Sea: A Human History of the Mediterranean, London: Penguin Books.

Allen, Robert C. (2011) Global Economic History: A Very Short Introduction, Cambridge: Cambridge University Press.

Althusser, Louis (1976) Essays in Self-Criticism, London: Verso.

Althusser, Louis (1984a) "Ideology and Ideological State Apparatuses (Notes towards an Investigation)", in Althusser, Louis , Essays on Ideology, London: Verso: 1-60.

Althusser, Louis (1984b) "Reply to John Lewis", Essays on Ideology, London: Verso: 61-139. Althusser, Louis (1990) For Marx, London: Verso.

Althusser, Louis (2006) Philosophy of the Encounter: Later writings 1978-87, London: Verso. Althusser, Louis , Étienne Balibar (1997) Reading Capital, London: Verso.

Althusser, Louis , Étienne Balibar , Roger Establet , Pierre Macherey , and Jacques Rancière (2015) Reading Capital, London: Verso.

Amin, Samir (1974) Accumulation on a World Scale, New York: Monthly Review Press.

Amin, Samir (1976) Unequal Development: An Essay on the Social Formations of Peripheral Capitalism, New York: Monthly Review Press.

Amin, Samir (1996) "The Ancient World-Systems versus the Modern Capitalist World System", in Frank, Andre G. and Barry K. Gills (eds.) The World System: Five Hundred Years or Five Thousand?, London and New York: Routledge.

Anderson, Perry (1974a) Passages from Antiquity to Feudalism, London: New Left Books. Anderson, Perry (1974b) Lineages of the Absolutist State, London: New Left Books.

Arbel, Benjamin , Bernard Hamilton and David Jacoby (eds.) (1989) Latins and Greeks in the Eastern Mediterranean after 1204, London and New York: Routledge.

Arrighi, Giovanni (1993) "The Three Hegemonies of Historical Materialism”, in Gill, Stephen (ed.) Gramsci, Historical Materialism and International Relations, Cambridge: Cambridge University Press: 148-185.

Arrighi, Giovanni (1996) The Long Twentieth Century, London and New York: Verso.

Arrighi, Giovanni (1999) "Globalization, State Sovereignty, and the 'Endless' Accumulation of Capital", in Smith, D. A. , D. J. Solinger and S. C. Topik (eds.) States and Sovereignty in the Global Economy, London and New York: Routledge.

Aston, Trevor Henry and Charles H. E. Philin (eds.) (1985) The Brenner Debate: Agrarian Class Struggle and Economic Development in Pre-Industrial Europe, Cambridge: Cambridge University Press.

Bakker, J. I. (Hans) (2003) "The Weber-Rachfahl Debate: Calvinism and Capitalism in Holland? (Part One)", Michigan Sociological Review, Vol. 17, (Fall): 119-148.

Balibar, Étienne (1983) "Sur le concept marxiste de la 'division du travail manuel et du travail intellectuel' et la lutte des classes", in Belkhir, Jean (ed.) L'Intellectuel: L'intelligentsia et les manuels, Paris: Anthropos, 97-117.

Balibar, Étienne (1984) "Marx et l' Entreprise", Politique Aujourd'hui, No. 5: 24-32.

Balibar, Étienne (1986) "Klassen/Klassenkampf", in Labica, G. and G. Bensussan (eds.)

Kritisches Wörterbuch des Marxismus, Vol. 4, Berlin: Argument: 615-636.

Balibar, Étienne (1997) "On the Basic Concepts of Historical Materialism", in Althusser, Louis and Etienne Balibar (eds.) Reading Capital, London: Verso: 199-308.

Banaji, Jairus (1977) "Modes of Production in a Materialist Conception of History", Capital \& Class, Vol. 3, No. 3: 1-43.

Banaji, Jairus (2003) "The Fictions of Free Labour: Contract, Coercion, and So-Called Unfree Labour", Historical Materialism, Vol. 11, No. 3: 69-95.

Banaji, Jairus (2010) Theory as History: Essays on Modes of Production and Exploitation, Leiden and Boston: Brill.

von Below, Georg (1926) Probleme der Wirtschaftsgeschichte, Berlin: Verlag von J.E.B. Mohr. Bernstein, Eduard (1895) Kommunistische und demokratisch-sozialistische Strömungen während der englischen Revolution, Stuttgart: J.H.W. Dietz.

Bernstein, Eduard (1980) Cromwell and Communism: Socialism and Democracy in the Great English Revolution, London: Spokesman Books. 
Bettelheim, Charles (1968) La Transition vers l'économie socialiste, Paris: Maspero.

Bettelheim, Charles (1974) Cultural Revolution and Industrial Organisation in China, New York: Monthly Review Press.

Bettelheim, Charles (1975) Economic Calculation and Forms of Property: An Essay on the Transition Between Capitalism and Socialism, New York: Monthly Review Press.

Blakemore, Richard J. (2017) "Pieces of eight, pieces of eight: seamen's earnings and the venture economy of early modern seafaring", Economic History Review, Vol. 70, No. 4:

1153-1184.

Bonefeld, Werner (2001) "The Permanence of Primitive Accumulation: Commodity Fetishism and Social Constitution", The Commoner, No. 2, September, www.commoner.org.uk

Bösch, Gerhard (2002) "The Serrata of the Great Council and Venetian Society", in Martin, John and Dennis Romano (eds.) Venice Reconsidered: The History and Civilization of an Italian City State, 1297-1797, Baltimore: The John Hopkins University Press: 67-88.

Bowd, Stephen D. (2010) Venice's most Loyal City: Civic Identity in Renaissance Brescia, Cambridge, MA and London: Harvard University Press.

Brass, Tom (2011) Labour Regime Change in the Twenty-First Century. Unfreedom, Capitalism and Primitive Accumulation, Leiden and Boston: Brill.

Braudel, Fernand (1972) The Mediterranean and the Mediterranean World in the Age of Philip II, London: Fontana/Collins.

Braudel, Fernand (1979) Afterthoughts on Material Civilization and Capitalism, Baltimore and London: The John Hopkins University Press.

Braudel, Fernand (1981) Civilization \& Capitalism 15th-18th Century. Vol. 1: The Structures of Everyday Life, New York: Harper \& Row.

Braudel, Fernand (1982) Civilization \& Capitalism 15th-18th Century. Vol. 2: The Wheels of Commerce, New York: Harper \& Row.

Braudel, Fernand (1984) Civilization \& Capitalism 15th-18th Century. Vol. 3: The Perspective of the World, New York: Harper \& Row.

Brecht, Bertolt (2008) Life of Galileo, London: Bloomsbury Publishing.

Brenner, Robert (1976) "Agrarian Structure and Economic Development in Pre-Industrial Europe", Past and Present, Vol. 70, No. 1: 30-75.

Brenner, Robert (1978) "Dobb on the Transition from Feudalism to Capitalism", Cambridge Journal of Economics, Vol. 2, No. 2: 121-140.

Brenner, Robert (1982) "The Agrarian Roots of European Capitalism", Past and Present, Vol. 97, No. 1: 16-113.

Brenner, Robert (1985) "The Agrarian Roots of European Capitalism", in Aston, Trevor Henry and Charles H. E. Philin (eds.) The Brenner Debate. Agrarian Class Struggle and Economic Development in Pre-Industrial Europe, Cambridge: Cambridge University Press: 213-327. Brenner, Robert (2001) "The Low Countries in the Transition to Capitalism", Journal of Agrarian Change, Vol. 1, No. 2: 169-241.

Brenner, Robert (2003) Merchants and Revolution: Commercial Change, Political Conflict and London's Overseas Traders 1550-1653, London and New York: Verso.

Brenner, Robert (2006) "What is, and what is not, imperialism? Historical Materialism, Vol. 14, No. 4: 79-105.

Brentano, Lujo (1916) Die Anfänge des modernen Kapitalismus, München: Verlag der K. B. Akademie der Wissenschaften.

Brentano, Lujo (1969 [1870]) On the History and Development of Gilds and the Origin of Trade Unions, New York: Burt Franklin.

Bresson, Alain (2016) The Making of the Ancient Greek Economy: Institutions, Markets and Growth in the City-States, Princeton and Oxford: Princeton University Press.

Brook, Timothy (ed.) (1989) The Asiatic Mode of Production in China, New York: M.E. Sharpe. Callinicos, Alex (2007) "Does Capitalism Need the State System", Cambridge Review of International Affairs, Vol. 20, No. 4: 533-549.

Callinicos, Alex (2010) Bonfire of Illusions: The Twin Crises of the Liberal World, Cambridge:

Polity Press.

Carchedi, Guglielmo (1977) On the Economic Identification of Social Classes, London:

Routledge \& Kegan Paul.

Chisholm, Hugh (ed.) (1911) "Comacchio", in Encyclopædia Britannica, Vol. 6, 11th ed.,

Cambridge: Cambridge University Press: 749. 
Cohen, Gerald A. (1989) History, Labour and Freedom: Themes from Marx, Cambridge: Cambridge University Press.

Cohen, Edward E. (1992) Athenian Economy and Society: A Banking Perspective, Princeton: Princeton University Press.

Cox, Oliver Cromwell (1959a) Caste, Class and Race: A Study in Social Dynamics, New York: Monthly Review Press.

Cox, Oliver Cromwell (1959b) The Foundations of Capitalism, London: Peter Owen Ltd. Cox, Oliver Cromwell (1964) Capitalism as a System, New York: Monthly Review Press. Crone, Patricia (2003) Pre-industrial Societies: Anatomy of the Pre-Modern World, London: Oneworld Publications.

Dante, Alighieri (2008) The Divine Comedy: Inferno, tr. Henry Wadsworth Longfellow, Digitalized version of the 1870 edition, Boston: Fields, Osgood, \& Co., www.gutenberg.org/cache/epub/1004/pg1004-images.html (accessed February 5, 2018). Davis, Robert, C. (2009) Shipbuilders of the Venetian Arsenal: Workers and Workplace in the Preindustrial City, Baltimore: The John Hopkins University Press.

Day, John (2002) "The Levant Trade in the Middle Ages", in Laiou, A. (ed.) The Economic History of Byzantium: From the Seventh through the Fifteenth Century, Washington DC: Dumbarton Oaks Research Library and Collection: 807-814.

Dean, Trevor and Chris Wickham (eds.) (1990) City and countryside in Late Medieval and Renaissance Italy: Essays Presented to Philip Jones, London and Ronceverte: The Hambledon Press.

De Angelis, Massimo (2007) The Beginning of History: Value Struggles and Global Capital, London: Pluto Press.

Deleuze, Gilles and Felix Guattari (1983) Anti-Oedipus. Capitalism and Schizophrenia, Minneapolis: University of Minnesota Press.

Deleuze, Gilles and Felix Guattari (1987) A Thousand Plateaus: Capitalism and Schizophrenia, Minneapolis: University of Minnesota Press.

Deleuze, Gilles and Felix Guattari (1994) What is Philosophy?, New York: Columbia University Press.

Denley, Peter (1990) "Governments and Schools in Late Medieval Italy", in Dean, Trevor and Chris Wickham (eds.) City and Countryside in Late Medieval and Renaissance Italy: Essays Presented to Philip Jones, London and Ronceverte: The Hambledon Press: 93-107.

Dobb, Maurice (1975) Studies in the Development of Capitalism, New York: International Publishers.

Dobb, Maurice (2006) "A Reply", in Hilton, R. (ed.) The Transition from Feudalism to Capitalism, Delhi: Aakar Books: 57-67.

Van Doosselaere, Quentin (2009) Commercial Agreements and Social Dynamics in Medieval Genoa, Cambridge: Cambridge University Press.

Dunbar, Charles F. (1892) "The Bank of Venice", The Quarterly Journal of Economics, Vol. 6, No. 3: 308-335.

Dutschke, Rudi (1974) Versuch, Lenin auf die Füsse zu stellen, Berlin: Wagenbach.

Ebner, Alexander (2000) "Schumpeter and the 'Schmollerprogramm': Integrating Theory and History in the Analysis of Economic Development", Journal of Evolutionary Economics, Vol. 10, No. 3: 355-372.

Economakis, George (2001) "Land Reform", in Barry Jones, R. J. (ed.) Encyclopedia of International Political Economy, Vol. 2, London and New York: Routledge: 901-902.

Economakis, George (2005) "Definition of the Capitalist Mode of Production: A Re-examination (with Application to Non-capitalist Modes of Production)", History of Economics Review, Vol. 42, No. 1: 12-28.

Economakis, George and John Milios (2001) "Historical School. German", in Barry Jones, R. J. (ed.) Encyclopedia of International Political Economy, Vol. 2, London and New York: Routledge: 686-687.

Emmanouilidis, Marios (2016) "Urban Panics and Black Holes. Ambiguities and Deceleration in the Time of Financialization", in Geheimagentur, Schäfer , Martin Jörg , and Vassilis S. Tsianos (eds.) The Art of Being Many. Towards a New Theory and Practice of Gathering, Bielefeld: transcript Verlag: 233-250.

Engels, Friedrich (1961) "Letter to Werner Sombart March 11 1895", in Beitrage zur Geschichte der deutscher Arbeiterbewegung No. 3. Reprint: Marx and Engels, Selected Works, Vol. 3: 
504-506, www.marxists.org/archive/marx/works/1895/letters/95_03_11.htm

Engels, Friedrich (2010) Origins of the Family, Private Property, and the State, London: Penguin Classics.

Ferguson, Niall (1999) The House of Rothschild: Money's Prophets 1798-1848, London:

Penguin Books.

Ferguson, Niall (2008) The Ascent of Money: A Financial History of the World, London: Penguin Books.

Ferraro, Joanne M. (2012) Venice: History of the Floating City, Cambridge: Cambridge University Press.

Finlay, George (2013) A History of Greece, Vol. 5: Greece Under Ottoman and Venetian Domination, Oxford: Oxford University Press.

Foreign Office, Miscellaneous series (1892) No 217. Report on the Condition of Labour in Russia, Athens: Historical Archive of the National Bank of Greece.

Fourtounis, George (2013) “'An Immense Aspiration to Being': The Causality and Temporality of the Aleatory", in Diefenbach, Katja , Sara R. Farris , Gal Kirn and Peter D. Thomas (eds.)

Encountering Althusser. Politics and Materialism in Contemporary Radical Thought, London and New York: Bloomsbury: 43-60.

Frank, Andre Gunter (1969) Kapitalismus und Unterentwicklung in Lateinamerika, Frankfurt/M.:

Europäische Verlagsanstalt.

Frank, Andre Gunter and Barry K. Gills (eds.) (1996) The World System: Five Hundred Years or Five Thousand?, London and New York: Routledge.

Fusaro, Maria (2015) Political Economies of Empire in the Early Modern Mediterranean: The Decline of Venice and the Rise of England, 1450-1700, Cambridge: Cambridge University Press.

Gerstein, Ira (1989) "(Re)Structuring Structural Marxism", Rethinking Marxism, Vol. 2, No. 1: 104-133.

Godelier, Maurice (1978) Sur les sociétés précapitalistes, Paris: Maspero.

Gramsci, Antonio (2007) Prison Notebooks, Vol. III, New York: Columbia University Press.

Greene, Molly (2000) A Shared World: Christians and Muslims in the Early Modern

Mediterranean, Princeton: Princeton University Press.

Haldon, John (1993) The State and the Tributary Mode of Production, London and New York:

Verso.

Haldon, John (ed.) (2009) A Social History of Byzantium, Oxford: Blackwell.

Harman, Chris (2004) "The Rise of Capitalism", International Socialism, No. 102.

http://www.isj.org.uk/?id=21 (accessed June 1, 2017).

Harman, Chris (2006) "Origins of Capitalism", International Socialism, No. 111.

www.isj.org.uk/index.php4?id=219\&issue=111 (accessed June 2, 2017).

Harnecker, Marta (2000) Conceptos Elementales del Materialismo Historico, Havana: Siglo Veintiuno.

Harrington, James (1992 [1656]) The Commonwealth of Oceana, Cambridge: Cambridge University Press.

Harvey, Alan (1989) Economic Expansion in the Byzantine Empire, 900-1200, Cambridge: Cambridge University Press.

Heck, Gene W. (2006) Charlemagne, Muhammad, and the Arab Roots of Capitalism, Berlin and New York: Walter de Gruyter.

Heinrich, Michael (2012) An Introduction to the Three Volumes of Karl Marx's Capital, New York: Monthly Review Press.

Heinsohn, Gunnar and Otto Steiger (1989) "The Veil of Barter", in Kregel, Jan A. (ed.) Inflation and Income Distribution in Capitalist Crisis, London: Macmillan: $175 \mathrm{ff}$.

Heller, Henry (2011) The Birth of Capitalism: A Twenty-First-Century Perspective, London: Pluto Press.

Hendy, Michael F. (1985) Studies in the Byzantine Monetary Economy c. 300-1450,

Cambridge: Cambridge University Press.

Hilton, Rodney (1952) "Capitalism - What's in a Name?", Past \& Present, Vol. 1, No. 1: 32-43.

Hilton, Rodney (1975) The English Peasantry in the Later Middle Ages, Oxford: Clarendon

Press.

Hilton, Rodney, (ed.) (2006a) The Transition from Feudalism to Capitalism, Delhi: Aakar Books. 
Hilton, Rodney (2006b) "Introduction", in Hilton, R. (ed.) The Transition from Feudalism to Capitalism, Delhi: Aakar Books: 9-30.

Hilton, Rodney (2006c) "A Comment", in Hilton, Rodney (ed.) The Transition from Feudalism to Capitalism, Delhi: Aakar Books: 109-117.

Hobsbawm, Eric (1992) Nations and Nationalism since 1780: Programme, Myth, Reality, Cambridge: Cambridge University Press.

Hoffman, Philip T. , Gilles Postel-Vinay and Jean-Laurent Rosenthal (2007) Surviving Large

Losses: Financial Crises, the Middle Class, and the Development of Capital Markets,

Cambridge, MA and London: Harvard University Press.

Holton, Robert J. (1985) The Transition from Feudalism to Capitalism, London: Macmillan

Education.

Holton, David (ed.) (2006) Literature and Society in Renaissance Crete, Cambridge: Cambridge University Press.

Hopkins, T. K. and I. Wallerstein (1979) "Grundzüge der Entwicklung des modernen

Weltsystems", in Senghaas, D. (ed.) Von Europa lernen. Entwicklungsgeschichtliche

Betrachtungen, Frankfurt/M.: Suhrkamp: $280 \mathrm{ff}$.

Howgego, Christopher (1995) Ancient History from Coins, London and New York: Routledge.

Hung, Hsueh-ping (1969) "The Essence of the 'Theory of Productive Forces' is to Oppose

Proletarian Revolution", Peking Review, No. 38: 5-8.

Hung, Kao (1969) "From Bernstein to Liu Shao-chi", Peking Review, No. 38: 8-9.

Iordanou, Ioanna (2016) "Pestilence, Poverty, and Provision: Re-evaluating the Role of the popolani in Early Modern Venice", The Economic History Review, Vol. 69, No. 3: 801-822.

Israel, Jonathan I. (2001) Radical Enlightenment: Philosophy and the Making of Modernity 1650-1750, Oxford: Oxford University Press.

Jacoby, David (1989) Latins and Greeks in the Eastern Mediterranean after 1204, London and New York: Routledge.

Jacoby, David (2001) Byzantium, Latin Romania and the Mediterranean, Aldershot: Ashgate. Jessop, Bob (1985) Nicos Poulantzas - Marxist Theory and Political Strategy, London and Basingstoke: Macmillan Publishers LTD.

Kaplan, Michael (2009) "The Producing Population", in Haldon, John (ed.) A Social History of Byzantium, Oxford: Blackwell: 143-167.

Katz, Claudio J. (1993) "Karl Marx on the Transition from Feudalism to Capitalism", Theory and Society, Vol. 22, No. 3: 363-389.

Kautsky, Karl (1988) The Agrarian Question, London: Zwan Publications.

Keynes, John Maynard (2013) The Collected Writings of John Maynard Keynes, Vol. XXVIII, Social, Political and Literary Writings, Cambridge: Cambridge University Press for the Royal Economic Society: 253-254.

Kyrtatas, Dimitris (2002) "Domination and Exploitation", in Cartledge, Paul , Edward E. Cohen and Lin Foxhall (eds.) Money, Labour and Land: Approaches to the Economies of Ancient Greece, London and New York: Routledge: 140-155.

Kyrtatas, Dimitris (2011) "Slavery and Economy in the Greek World", in Bradley, Keith and Paul Cartledge (eds.) The Cambridge World History of Slavery, Cambridge: Cambridge University Press: 91-111.

Lacher, Hannes (2005) "International Transformation and the Persistence of Territoriality: Toward a New Political Geography of Capitalism", Review of International Political Economy, Vol. 12: No. 1: 26-52.

Laibman, David (2007) Deep History: A Study of Social Evolution and Human Potential, New York: SUNY Series in Radical Social and Political Theory.

Laiou, Angeliki E. (ed.) (2002a) The Economic History of Byzantium: From the Seventh through the Fifteenth Century, Washington DC: Dumbarton Oaks Research Library and Collection. Laiou, Angeliki E. (2002b) "The Agrarian Economy, Thirteenth-Fifteenth Centuries", in Laiou, Angeliki (ed.) The Economic History of Byzantium: From the Seventh through the Fifteenth Century, Washington DC: Dumbarton Oaks Research Library and Collection: 311-375.

Laiou, Angeliki E. (2002c) "The Byzantine Economy: An Overview", in Angeliki, Laiou (ed.) The Economic History of Byzantium: From the Seventh through the Fifteenth Century, Washington DC: Dumbarton Oaks Research Library and Collection: 1145-1164.

Lane, Frederic C. (1966) Venice and History: The Collected Papers of Frederic C. Lane, Baltimore: The John Hopkins University Press. 
Lane, Frederic C. (1973) Venice, a Maritime Republic, Baltimore and London: The John Hopkins University Press.

Lane, Frederic C. (1979) Profits from Power: Readings in Protection Rent and ViolenceControlling Enterprises, Albany: State University of New York.

Law, John E. (1992) "The Venetian Mainland State in the Fifteenth Century", Transactions of the Royal Historical Society, Vol. 2: 153-174.

Le Goff, Jacques (1980) Time, Work and Culture in the Middle Ages, Chicago and London: The University of Chicago Press.

Lenin, Vladimir I. (1917) Letters from Afar,

http://www.marxists.org/archive/lenin/works/1917/lfafar/first.htm, (accessed October 2, 2017).

Lenin, Vladimir I. (1977) Collected Works, Vols. 1-4, Moscow: Progress Publishers.

Lilie, Ralph-Johannes (1994) Byzantium and the Crusader States 1096-1204, Cambridge:

Clarendon Press.

Linebaugh, Peter and Marcus, Rediker (2001) The Many-Headed Hydra. Sailors, Slaves, Commoners, and the Hidden History of the Revolutionary Atlantic, Boston: Beacon Press. Lukács, Georg (2009) Lenin: A Study on the Unity of his Thought, London and New York: Verso.

Luxemburg, Rosa (1971) The Accumulation of Capital, London: Routledge and Kegan Paul. Machiavelli, Niccolò (1981) The Prince, London: Penguin classics.

Madden, Thomas F. (2003) Enrico Dandolo and the Rise of Venice, Baltimore: The John Hopkins University Press.

Mallet, Michael E. and John R. Hale (1984) The Military Organisation of a Renaissance State. Venice c. 1400 to 1617, Cambridge: Cambridge University Press.

Maltezou, Chryssa (2006) "The Historical and Social Context", in Holton, David (ed.) Literature and society in Renaissance Crete, Cambridge: Cambridge University Press: 17-48.

Mandel, Ernest (1968) Marxist Economic Theory, Vol. 2, London: Merlin.

Mandel, Ernest (1971) The Formation of the Economic Thought of Karl Marx, New York and London: Monthly Review Press: 9-90.

Mandel, Ernest (1991) "Introduction", in Marx, Karl Capital. A Critique of Political Economy, Vol. 3, London: Penguin Classics.

Mao, Tsetung (1977) A Critique of Soviet Economics, London and New York: Monthly Review Press.

Maridaki-Karatza, Olga (2002) "Legal Aspects of the Financing of Trade", in Laiou, Angeliki (ed.) The Economic History of Byzantium: From the Seventh through the Fifteenth Century,

Washington DC: Dumbarton Oaks Research Library and Collection: 1105-1120.

Marin, Serban V. (2013) "Marcantonio Sabellico's Rerum Venetarum and 'the Definitive History of Venice'. The Beginnings of the Official Historiography in Venice?", Revista Arhivelor, Vol.

XC/2013, No. 1-2: 134-177.

Martin, John and Dennis Romano (eds.) (2000a) Venice reconsidered: the history and civilization of an Italian city state, 1297-1797, Baltimore: The John Hopkins University Press. Martin, John and Dennis Romano (2000b) "Reconsidering Venice", in Martin, John and Dennis Romano , (eds.) Venice Reconsidered: The History and Civilization of an Italian City State, 1297-1797, Baltimore: The John Hopkins University Press: 1-35.

Marx-Engels-Werke (MEW) (1976), Karl Marx Friedrich Engels Werke, Institut für MarxismusLeninismus beim ZK der SED, vols. 8-38, Berlin: Dietz Verlag.

Marx, Karl (1864) Results of the Direct Production Process, Draft Chapter 6 of Vol. 1 of Capital, tr. Ben Fowkes, http://www.marxists.org/archive/marx/works/1864/economic/ (accessed

December 14, 2017).

Marx, Karl (1887) Capital. A Critique of Political Economy, Vol. 1

www.marxists.org/archive/marx/works/download/pdf/Capital-Volume-I.pdf (accessed December 2, 2017).

Marx, Karl (1968) Theories of Surplus Value, Part II, Moscow: Progress Publishers.

Marx, Karl (1976) "Notizen zur Reform von 1861 in Russland", MEW, Vol. 19, Berlin: Dietz Verlag: 407-424.

Marx, Karl (1987) A Contribution to the Critique of Political Economy, in Marx, Karl and Friedrich Engels (eds.) Collected Works, Moscow: Progress Publishers: 257-417.

Marx, Karl (1989) "Circular letter to August Bebel, Wilhelm Liebknecht, Wilhelm Bracke and Others", in Marx, Karl and Friedrich Engels (eds.) Collected Works, Vol. 24, Moscow: Progress 
Publishers: 253-269.

Marx, Karl (1991) Capital. A Critique of Political Economy, Vol. 3, London: Penguin Classics. Marx, Karl (1992) Capital, A Critique of Political Economy, Vol. 2, London: Penguin Classics. Marx, Karl (1993) Grundrisse, London: Penguin Classics.

Marx, Karl (2010) "Economic Manuscript of 1861-63 (Continuation)", in Marx, Karl and Friedrich Engels (eds.) Collected Works, Vol. 33, Chadwell Heath: Lawrence and Wishart. Marx, Karl and Friedrich Engels (1985) The Communist Manifesto, London: Penguin Classics. Marx, Karl and Friedrich Engels (1989) Marx-Engels Collected Works (MECW), Vol. 24, New York: International Publishers.

Marx, Karl and Friedrich Engels (1998) The German Ideology including Theses on Feuerbach and Introduction to the Critique of Political Economy, Amherst, NY: Prometheus Books.

Matschke, Klaus-Peter (2002) "Commerce, Trade, Markets, and Money: Thirteenth-Fifteenth Centuries" in Angeliki, Laiou (ed.) The Economic History of Byzantium: From the Seventh through the Fifteenth Century, Washington DC: Dumbarton Oaks Research Library and Collection: 771-806.

McKee, Sally (1994) "The Revolt of St Tito in Fourteenth-Century Venetian Crete: A Reassessment", Mediterranean Historical Review, Vol. 9, No. 2: 173-204.

McKee, Sally (2004) "Inherited Status and Slavery in Late Mediterranean Italy and Venetian Crete", Past and Present, No. 182: 31-53.

McKee, Sally (2008) "Domestic Slavery in Renaissance Italy", Slavery and Abolition, Vol. 29, No. 3: 305-326.

Meikle, Scott (1995) Aristotle's Economic Thought, Oxford: Clarendon Press.

Merrington, John (2006) "Town and Country in the Transition to Capitalism", in Hilton, Rodney (ed.) The Transition from Feudalism to Capitalism, Delhi: Aakar Books: 170-195.

Milios, Jean (1988) Kapitalistische Entwicklung, Nationalstaat und Imperialismus. Der Fall Griechenland, Athens: Kritiki.

Milios, John (1989) "The Problem of Capitalist Development: Theoretical Considerations in View of the Industrial Countries and the New Industrial Countries", in Gottdiener, M. and N. Komninos (eds.) Capitalist Development and Crisis Theory, London: Macmillan.

Milios, John (1997) "Der Marxsche Begriff der asiatischen Produktionsweise und die theoretische Unmöglichkeit einer Geschichtsphilosophie", Beiträge zur Marx-Engels-Forschung. Neue Folge, Berlin: Argument Verlag.

Milios, John (1999) "Preindustrial Capitalist Forms: Lenin's Contribution to a Marxist Theory of Economic Development", Rethinking Marxism, Vol. 11, No. 4 (Winter): 38-56.

Milios, John (2000) "Social Classes in Classical and Marxist Political Economy", American Journal of Economics and Sociology, Vol. 59, No. 2 (April): 283-302.

Milios, John (2002) "Theory of Value and Money. In Defence of the Endogeneity of Money"; in Sixth International Conference in Economics - Economic Research Center, METU, Ankara, September 11-14.

Milios, John, Dimitri Dimoulis and George Economakis (2002) Karl Marx and the Classics, an Essay on Value, Crises and the Capitalist Mode of Production, Aldershot: Ashgate.

Milios, John and Dimitris P. Sotiropoulos (2009) Rethinking Imperialism: A Study of Capitalist Rule, London: Palgrave Macmillan.

Milios, John and George Economakis (2011) "The Middle Classes, Class Places, and Class Positions: A Critical Approach to Nicos Poulantzas's Theory", Rethinking Marxism, Vol. 23, No. 2: 226-245.

Millett, Paul (1991) Lending and Borrowing in Ancient Athens, Cambridge: Cambridge University Press.

Mommsen, Wolfgang J. and Jürgen Osterhammel (eds.) (1987) Max Weber and His Contemporaries, New York: HarperCollins.

Montag, Warren (2003) Althusser, Houndmills and New York: Palgrave Macmillan. Morfino, Vittorio (2005), "An Althusserian Lexicon", Borderlands e-journal, Vol. 4, No. 2, www.borderlands.net.au/vol4no2_2005/morfino_lexicon.htm, (accessed October 2, 2017). Morrisson, Cécile (2002) "Byzantine Money: Its Production and Circulation", in Laiou, Angeliki (ed.) The Economic History of Byzantium: From the Seventh through the Fifteenth Century, Washington DC: Dumbarton Oaks Research Library and Collection: 909-966.

Müller, Wolfgang (1975) "Momente des bürgerlichen Staates in der griechischen Polis", Probleme des Klassenkampfs, No. 17/18: 1-25. 
Nails, Debra (2002) The People of Plato: A Prosopography of Plato and Other Socratics, Indianapolis and Cambridge: Hackett Publishing Company.

Nicol, Donald M. (1988) Byzantium and Venice: A Study in Diplomatic and Cultural Relations, Cambridge: Cambridge University Press.

O'Connell, Monique (2009) Men of Empire: Power and Negotiation in Venice's Maritime State, Baltimore: The John Hopkins University Press.

Oliphant, Mrs. (1889) The Makers of Venice. Doges, Conquerors, Painters, and Men of Letters, London and New York: Macmillan and Co.

Papagianni, Eleutheria (2002) "Byzantine Legislation on Economic Activity Relative to Social Class", in Laiou, Angeliki (ed.) The Economic History of Byzantium: From the Seventh through the Fifteenth Century, Washington DC: Dumbarton Oaks Research Library and Collection: 1083-1093.

Pashukanis, Evgeny B. (1978) Law and Marxism: A General Theory, London: Pluto Press. Peking Review (1969) Issue No. 38, September 19, www.marxists.org/subject/china/pekingreview/1969/PR1969-38.pdf

Pellicani, Luciano (1994) The Genesis of Capitalism and the Origins of Modernity, New York: Telos Press.

Penna, Daphne (2012) The Byzantine Imperial Acts to Venice, Pisa and Genoa, 10th-12th centuries, A Comparative Legal Study, Groningen: Eleven International Publishing.

Perelman, Michael (2000) The Invention of Capitalism: Classical Political Economy and the Secret History of Primitive Accumulation, Durham: Duke University Press.

van der Pijl, Kees (2006) Global Rivalries: From the Cold War to Iraq, London: Pluto Press. Pirenne, Henri (2014) Medieval Cities: Their Origins and the Revival of Trade, Princeton and Oxford: Princeton University Press.

Plekhanov, Georgi V. (1898) "On the Role of the Individual in History", www.marxists.org/archive/plekhanov/1898/xx/individual.html

Polanyi, Karl (1971) "Aristotle's Discourse on the Economy" in Polanyi, Karl , Conrad M.

Arensberg and Harry W. Pearson (eds.), Trade and Market in the Early Empires: Economies in History and Theory, Chicago: Henry Regnery: 64-94.

Poulantzas, Nicos (1973) Political Power and Social Classes, London: New Left Books.

Poulantzas, Nicos (1975) Classes in Contemporary Capitalism, London: New Left Books.

Poulantzas, Nicos (1976) "The Capitalist State: A Reply to Miliband and Laclau", New Left Review, No. 95: 63-83.

Poulantzas, Nicos (1980) State, Power, Socialism, London and New York: Verso.

Pryor, John H. (1977) "The Origins of the Commenda Contract", Speculum, Vol. 52, No. 1: 5-37.

Pullan, Brian (2001) "Jewish Bankers and Monti di Pietà", in Davis, Robert C. and Benjamin Ravid (eds.), The Jews of Early Modern Venice, Baltimore and London: The John Hopkins University Press: 53-72.

Rachfahl, Felix (1906) Wilhelm von Oranien und der niederlaendische Aufstand, Band I, Halle: Verlag von Max Niemeyer.

Rachfahl, Felix (1907) Wilhelm von Oranien und der niederlaendische Aufstand, Band II Abteilung I, Halle: Verlag von Max Niemeyer.

Rachfahl, Felix (1908) Wilhelm von Oranien und der niederlaendische Aufstand, Band II, Abteilung II, Halle: Verlag von Max Niemeyer.

Rafie, Kaveh (2013) "The Philosophical Role of Cephalus in the Republic", www.academia.edu/3167386/The_Philosophical_Role_of_Cephalus_in_the_Republic Read, Jason (2002) "Primitive Accumulation: The Aleatory Foundation of Capitalism", Rethinking Marxism, Vol. 14, No. 2: 24-49.

Rediker, Marcus (1989) "The Common Seaman in the Histories of Capitalism and the Working Class", International Journal of Maritime History, Vol. 1, No. 2: 337-357.

Resnick, Stephen and Richard Wolff (1979) "The Theory of Transition Conjunctures and the Transition from Feudalism to Capitalism in Western Europe", Review of Radical Political Economics, Vol. 11, No. 3 (Fall): 3-22.

Rey, Pierre-Philippe (1973) Les Alliances de Classes, Paris: Francois Maspero.

Richards, Alan (1986) Development and Modes of Production in Marxian Economics: A Critical Evaluation, London and New York: Harwood Academic Publishers. 
Rosdolsky, Roman (1969) Zur Entstehungsgeschichte des Marxschen "Kapital", Vol. II, Frankfurt/M.: EVA.

Rubin, Isaac I. (1979) A History of Economic Thought, London: Pluto Press.

Ruggiero Guido (1978) "Law and Punishment in Early Renaissance Venice", Journal of Criminal Law and Criminology, Vol. 69, No. 2: 243-256.

Sayers, Sean (1980) "Forces of Production and Relations of Production in Socialist Society", Radical Philosophy, No. 24, (Spring): 12-18.

Schaal, Hans (1931) Vom Tauschhandel zum Welthandel. Bilder vom Handel und Verkehr der Vorgeschichte und des Altertums, Leipzig und Berlin: Verlag und Druck von B.G. Teubner. von Schmoller, Gustav (1903) "Werner Sombart, Der moderne Kapitalismus", Schmollers Jahrbuch für Gesetzgebung, Verwaltung und Volkswirtschaft im Deutschen Reiche, Vol. 51: 349-369.

Schumpeter, Joseph A. (September 1928) "The Instability of Capitalism", The Economic Journal, Vol. 38, No. 151: 361-386.

Semenova, Alla and L. Randall Wray (2015) "The Rise of Money and Class Society: The Contributions of John F. Henry", Levy Economics Institute of Bard College, Working Paper No. 832.

Senghaas, Dieter (ed.) (1982) Von Europa lernen. Entwicklungsgeschichtliche Betrachtungen, Frankfurt/M.: Suhrkamp.

Senior, Nassau (1951) An Outline of the Science of Political Economy, London: Allen \& Unwin. Sherrard, Philip (1966) Byzantium, New York: Time Incorporated.

Sieveking, Heinrich (1935) Wirtschaftsgeschichte, Berlin: Verlag Julius Springer.

Smith, Adam (2007) An Inquiry into the Nature and Causes of the Wealth of Nations, 2 vols., Indianapolis: Liberty Classics.

Sombart, Werner (1894) "Zur Kritik des ökonomischen Systems von Karl Marx", Archiv für soziale Gesetzgebung und Statistik, Vol. 7, No. 4: 555-594.

Sombart, Werner (1898) Socialism and the Social Movement in the 19th Century, with an Introduction by John B. Clark, London and New York: G. P. Putnam's Sons.

Sombart, Werner (1902) Der moderne Kapitalismus. Erster Band. Die Genesis des Kapitalismus, Leipzig: Verlag von Duncker \& Humblot.

Sombart, Werner (1913) Der Bourgeois. Zur Geistesgeschichte des modernen Kapitalismus, München und Leipzig: Verlag von Duncker \& Humblot.

Sombart, Werner (1915) The Quintessence of Capitalism: A Study of the History and Psychology of the Modern Business Man, London: T. Fisher Unwin, Ltd.

Sombart, Werner (1916a) Der moderne Kapitalismus. Historisch-systematische Darstellung des gesamteuropäischen Wirtschaftslebens von seinen Anfängen bis zur Gegenwart. Erster Band. Einleitung - Die vorkapitalistische Wirtschaft - Die historischen Grundlagen des modernen Kapitalismus, München und Leipzig: Verlag von Duncker \& Humblot.

Sombart, Werner (1916b) Der moderne Kapitalismus. Historisch-systematische Darstellung des gesamteuropäischen Wirtschaftslebens von seinen Anfängen bis zur Gegenwart. Zweiter Band. Das europäische Wirtschaftsleben im Zeitalter des Frühkapitalismus vornehmlich im 16., 17. und 18. Jahrhundert, München und Leipzig: Verlag von Duncker \& Humblot.

Sombart, Werner (1967) Luxury and Capitalism, Ann Arbor: University of Michigan Press. Sombart, Werner (2001) The Jews and Modern Capitalism, Kitchener: Batoche Books.

Sophocles, Antigone [441 BC], Sir Richard Jebb (ed.), Perseus Digital Library, http://www.perseus.tufts.edu/hopper/

Sotiropoulos, Dimitris P. , John Milios and Spyros Lapatsioras (2013) A Political Economy of Contemporary Capitalism and its Crisis: Demystifying Finance, London and New York: Routledge.

Spinoza, Baruch (2002) "Political Treatise", in Morgan, Michael L. (ed.), The Complete Works, Indianapolis: Hackett Publishing Company: 676-754.

Stalin, Joseph (1975) Dialectical and Historical Materialism, Calcutta: Mass Publications. Stallsmith, Allaire B. (2007) "One Colony, Two Mother Cities: Cretan Agriculture under Venetian and Ottoman Rule", in Davies, Siriol and Jack L. Davis (eds.), Between Venice and Istanbul: Colonial Landscapes in Early Modern Greece, Athens: Hesperia Supplements, The American School of Classical Studies at Athens: 151-171.

Ste. Croix , G.E.M., de (1981) The Class Struggle in the Ancient Greek World, New York: Cornell University Press. 
Ste. Croix , G.E.M., de (1984) "Class in Marx's Conception of History, Ancient and Modern." New Left Review, No. 146: 92-111.

Ste. Croix , G.E.M., de (2004) Athenian Democratic Origins and Other Essays, Oxford: Oxford University Press.

Sternberg, Fritz (1971). Der Imperialismus, Frankfurt/M.: Verlag Neue Kritik.

Strieder, Jakob (1968) Zur Genesis des modernen Kapitalismus. Forschungen zur Entstehung der großen bürgerlichen Kapitalvermögen am Ausgange des Mittelalters und zu Beginn der Neuzeit, zunächst in Augsburg, Zweite, vermehrte Ausgabe, New York: Burt Franklin.

Suchting, Wal (1982) "'Productive Forces' and 'Relations of Production' in Marx", Analyse und Kritik, No. 4: 159-181.

Sweezy, Paul (2006) "A Critique", in Hilton, Rodney (ed.) The Transition from Feudalism to Capitalism, Delhi: Aakar Books: 33-56.

Takahashi, Kohachiro (2006) "A Contribution to the Discussion", in Hilton, Rodney (ed.) The Transition from Feudalism to Capitalism, Delhi: Aakar Books: 68-97.

Tawney, Richard Henry (1963) Religion and the Rise of Capitalism, New York: Mentor Books. Teschke, Benno (2003) The Myth of 1648: Class, Geopolitics and the Making of Modern International Relations, London and New York: Verso.

Teschke, Benno and Hannes Lacher (2007) "The Changing 'Logics' of Capitalist Competition", Cambridge Review of International Affairs, Vol. 20, No. 4: 565-580.

The National Archives (2017) "Getting the vote: Voting rights before 1832", www.nationalarchives.gov.uk/pathways/citizenship/struggle_democracy/getting_vote.htm (accessed October 2, 2017).

Udovitch, Abraham (1970) Partnership and Profits in Medieval Islam, Princeton: Princeton University Press.

Vasiliev, Alexander A. (1952) History of the Byzantine Empire 324-1453, Madison: The University of Wisconsin Press.

Wallerstein, Immanuel (1974) The Modern World System, New York: Academic Press. Wallerstein, Immanuel (1979) "Aufstieg und künftiger Niedergang des kapitalistischen Weltsystems", in Senghaas, D. (ed.) Kapitalistische Weltökonomie, Frankfurt/M.: Suhrkamp Verlag.

Wallerstein, Immanuel (1980) The Modern World System II, New York: Academic Press. Wallerstein, Immanuel (1996) "World System versus World-Systems: A Critique", in Frank, A. G. and B. K. Gills (eds.) The World System: Five Hundred Years or Five Thousand?, London and New York: Routledge.

Weber, Max (2001) The Protestant Ethic and the Spirit of Capitalism, London and New York: Routledge.

Whitfield, John Humphreys (1966) Petrarch and the Renascence, New York: Haskell House. Wickham, Chris (2015) Sleepwalking into a New World: The Emergence of Italian City Communes in the Twelfth Century, Princeton and Oxford: Princeton University Press. Wolf, Eric R. (1982) Europe and the People Without History, Berkeley and Los Angeles: University of California Press.

Wood, Ellen Meiksins (1991) The Pristine Culture of Capitalism, London: Verso.

Wood, Ellen Meiksins (2002) The Origins of Capitalism: A Longer View, London: Verso. Wood, Ellen Meiksins (2003) Empire of Capital, London and New York: Verso.

Wray, L. Randall (1993) "The Origins of Money and the Development of the Modem Financial System", The Jerome Levy Economics Institute of Bard College and University of Denver, Working Paper No. 86, March.

Zolotas, Georgios I. (1924) Istoria tis Chiou (History of Chios), Vol. B, Athens: Sakellariou. 